\title{
PENYULUHAN PENTINGNYA LITERASI DI MASA PANDEMIK PADA SISWA SMK PROFITA BANDUNG TAHUN AJARAN 2020/2021
}

\author{
Yulia Herliani $^{1}$, Heri Isnaini ${ }^{2}$, Peni Puspitasari ${ }^{3}$ \\ ${ }^{1)}$ SMK Profita Bandung, Indonesia \\ e-mail: yuliaherliani1986@gmail.com \\ ${ }^{2)}$ Program Studi Pendidikan Bahasa dan Sastra Indonesia, IKIP Siliwangi, Cimahi, Indonesia \\ $e$-mail: heriisnaini1985@gmail.com \\ ${ }^{3)}$ Program Studi Pendidikan Bahasa Indonesia, Universitas Wisnuwardhana Malang, Indonesia \\ e-mail: penipuspitasari89@yahoo.com
}

\begin{abstract}
Abstrak
Penyuluhan ini bertujuan untuk menunjukkan pentingnya literasi pada siswa SMK terlebih di masa pandemik Covid 19. Literasi merupakan bagian dari proses peningkatan kemampuan siswa dalam memahami kompetensi dan peningkatan kemampuan berpikirnya. Kegiatan literasi adalah penghela untuk meningkatkan kemampuan siswa di bidang kompetensi sesuai dengan bidang keahliannya masing-masing. Siswa SMK yang sudah dibekali dengan bidang keahlian akan dibantu dengan maksimal dengan program literasi yang terarah dan terukur. SMK Profita kota Bandung adalah sekolah kejuruan yang memiliki 3 bidang keahlian, yaitu bidang keahlian akuntansi keuangan lembaga; otomatisasi tata kelola perkantoran, dan bisnis daring pemasaran. Ketiga bidang keahlian tersebut dapat dimaksimalkan dengan wujud literasi yang baik dan efektif. Gerakan Literasi Sekolah (GLS) adalah wujud keseriusan pemerintah dan sekolah dalam memaksimalkan literasi di sekolah. Gerakan ini menjadi tanggung jawab semua warga sekolah untuk meningkatkan kompetensi siswa melalui gerakan literasi. Penyuluhan ini dilakukan dengan tiga tahapan, yaitu: (1) pengumpulan data dengan observasi dan pengamatan langsung; (2) persiapan penyuluhan yang terdiri atas persiapan materi dan media daring yang digunakan; (3) pelaksanaan penyuluhan dengan proses pemberian materi melalui media daring; (4) Evaluasi kegiatan. Hasil dari kegiatan penyuluhan ini menunjukkan tingkat literasi yang rendah dipengaruhi oleh beberapa faktor, seperti: faktor ketersediaan bahan literasi, ketidaktahuan siswa, kurangnya motivasi berliterasi, dan teknik membaca yang salah. Dengan demikian, penyuluhan ini adalah usaha dan upaya untuk menumbuhkembangkan kegiatan literasi pada siswa SMK sehingga literasi dapat menjadi bagian untuk meningkatkan keahlian siswa.
\end{abstract}

Kata Kunci: Gerakan Literasi Sekolah, Keterampilan Membaca, Kompetensi, Siswa SMK

\begin{abstract}
This counseling aims to show the importance of literacy in vocational school students especially during the Covid 19 pandemic. Literacy is part of the process of improving students' ability to understand competencies and improve their thinking skills. Literacy activities are used to improve students' ability in competency according to their respective areas of expertise. Vocational school students who have been equipped with areas of expertise will be helped to the maximum with a targeted and measured literacy program. SMK Profita bandung is a vocational school that has 3 areas of expertise, namely the field of financial accounting expertise of institutions; automation of office governance, and online business marketing. These three areas of expertise can be maximized with a good and effective form of literacy. The School Literacy Movement (GLS) is a manifestation of the seriousness of the government and schools in maximizing literacy in schools. This movement is the responsibility of all school residents to improve the competence of students through the literacy movement. This counseling is done in three stages, namely: (1) data collection with observation and direct observation; (2) preparation of counseling consisting of the preparation of materials and online media used; (3) the implementation of counseling by the process of providing material through online media; (4) Evaluation of activities. The results of this counseling
\end{abstract}


activity showed low literacy rates influenced by several factors, such as: literacy material availability factors, student ignorance, lack of literacy motivation, and incorrect reading techniques. Thus, this counseling is an effort and effort to develop literacy activities in vocational school students so that literacy can be part of improving students' skills.

Keywords: School Literacy Movement, Reading Skills, Competency, Vocational School Students

\section{PENDAHULUAN}

Penyuluhan ini dilaksanakan dalam rangka memberikan informasi terkait tentang pentingnya literasi pada siswa SMK. Kegiatan ini dilaksanakan bertepatan dengan kegiatan Masa Pengenalan Lingkungan Sekolah 2020 secara daring. Dengan kegiatan ini, diharapkan siswa dapat mengenal lingkungan sekolah dari aspek fisik dan dari aspek intelektual. Selain, dari pengenal lingkungan sekolah secara umum, siswa juga dibekali dengan pemahaman akan pentingnya literasi. Literasi merupakan kemampuan yang harus dimiliki oleh seseorang dalam mengakses, memahami, dan menggunakan alat atau sesuatu secara benar dan efektif. Kemampuan-kemampuan ini menjadi bagian penting dengan objek siswa sebagai bagian dari pembentukan karakter manusia yang cerdas, yakni manusia yang mampu mengembangkan diri secara efektif menggunakan akal dan kemampuan yang logis.

Sebagai bagian yang penting di dalam pengembangan kompetensi siswa, literasi dapat diupayakan lebih efektif dan lebih berdaya guna. Hal ini ditegaskan pendapat Gardner (1983: 49) yang mengungkapkan sembilan kecerdasan yang dimiliki manusia. Sembilan kecerdasan ini berbasis kemampuan literasi yang maksimal. Adapun Sembilan kecerdasan itu adalah: kecerdasan linguistik, matematis-logis, spasial, interpersonal, intrapersonal, kinestetik-jasmani, musikal, dan naturalis (Gardner, 1983: 49). Kesembilan kecerdasan itu harus bermuara pada kegiatan literasi yang efektif.

Penelitian Yulisa Wandasari (2017) tentang "Implementasi Gerakan Literasi Sekolah (GLS) sebagai Pembentuk Pendidikan Berkarakter" menunjukkan bahwa gerakan literasi di SMK Negeri 1 Tanah Abang dapat membentuk karakter yang dilakukan dengan implementasi Gerakan Literasi Sekolah, yakni membaca. Sementara itu, penelitian Lisa Nopilda dan Muhammad Kristiawan (2018) tentang "Gerakan Literasi Sekolah Berbasis Pembelajaran Multiliterasi sebuah Paradigma Pendidikan Abad ke-21" menjelaskan Gerakan Literasi Sekolah (GLS) berbasis pembelajaran multiliterasi sebagai paradigma pendidikan abad-21 bertujuan untuk menumbuhkan sikap budi pekerti luhur kepada anak-anak melalui keterampilan memahami bacaan, menulis karya, dan mengkomunikasikan dengan bahasa lisan yang efektif.

Gerakan Literasi Sekolah merupakan suatu usaha atau kegiatan yang bersifat partisipatif dengan melibatkan warga sekolah (peserta didik, guru, kepala sekolah, tenaga kependidikan, pengawas sekolah, Komite Sekolah, orang tua/ wali murid peserta didik), dan pemangku kepentingan di bawah koordinasi Direktorat Jenderal Pendidikan Dasar dan Menengah Kementerian Pendidikan dan Kebudayaan. Dengan adanya dukung serta, komitmen dari pelaksana, maka tidak ada alasan kebijakan tidak dapat berjalan dengan baik (Wandasari, 2017: 342). Dengan demikian gerakan literasi sekolah merupakan gerakan kelompok yang kolaboratif dari berbagai elemen. Upaya-upaya ini dapat dilakukan dengan kegiatan membaca yang konsisten dan berulangulang daalam kurun waktu yang panjang.

Membaca adalah salah satu keterampilan berbahasa yang sifatnya reseptif. Dalam konsep keterampilan berbahasa, kemampuan dan keterampilan berbahasa menjadi keterampilan dasar yang dapat memacu kompetensi yang lain. Ada beberapa faktor penting dalam pembelajaran, yang salah satunya adalah membaca. Membaca merupakan salah satu kegiatan dalam berliterasi. Literasi tidak dapat dipisahkan dari dunia pendidikan. Literasi menjadi sarana peserta didik dalam mengenal, memahami, dan menerapkan ilmu yang didapatkannya di bangku sekolah (Budiharto, Triyono, \& Suparman, 2018: 154).

Selain faktor membaca, faktor lingkungan merupakan faktor dapat mempengaruhi kompetensi siswa. Lingkungan sekolah harus mengambil peran penting dalam meningkatkan kemampuan siswa dalam mencapai kompetensinya. Kelengkapan sarana dan prasarana dalam belajar serta 
kondisi lingkungan sekolah yang sangat baik penting guna untuk mendukung terciptanya suasana lingkungan belajar mengajar yang menyenangkan.

Sebagai suatu lembaga yang memberikan kesempatan belajar dan menyelenggarakan pengajaran harus memenuhi bermacam-macam persyaratan antara lain: murid, guru, program pendidikan, asrama, sarana dan fasilitas. Segala sesuatu sudah disusun dan diatur menurut pola dan sisitematika tertentu sehingga memungkinkan kegiatan belajar dan mengajar berlangsung dengan efektif dan baik dan terarah pada pembentukan dan pengembangan siswa (Mujiwati, Paramitha, \& Maulana, 2020: 158).

Pada situasi pandemik seperti sekarang ini, lingkungan sekolah sebagai sarana pembelajaran yang efektif tidak dapat dilaksanakan lagi akibat dari kebijakan pemerintah untuk menekan penyebaran Covid 19. Kebijakan pemerintah untuk menutup sementara sekolah jelas berimbas pada cara dan metode pengajaran dan pembelajaran di sekolah. Pembelajaran daring menjadi pilihan yang tidak terelakkan lagi untuk mengatasi masalah pembelajaran. Media yang digunakan sangat beragam, mulai dari media zoom, google classroom, google meet, dan sebagainya.

Pembelajaran Online atau dikenal dengan pembelajaran elektronik, atau e-learning adalah pembelajaran yang disampaikan dengan memanfaatkan elektronik seperti komputer. Umumnya untuk mengakses materi online learning melalui jaringan, website, internet, intranet, CD dan DVD (Arriany, Junadi, \& Laksono, 2020: 119-120). Merujuk pada definisi tersebut, dapat disimpulkan bahwa online learning adalah lingkungan pembelajaran yang menggunakan komputer, internet untuk mengakses pembelajaran, untuk berinteraksi dengan konten pembelajaran, instruktur dan pembelajar lain serta memberikan dukungan selama proses pembelajaran sebagai usaha untuk mendapatkan, membentuk pengetahuan dan membangun pengalaman belajar. Karakteristik dari pembelajaran online adalah (1) materi pembelajaran dibuat dari teks, grafik, multimedia seperti video, audio dan animasi (2) aplikasi komunikasi synchrounous (langsung) dan asynchronous (tidak langsung).

Berdasarkan penjelasan tersebut, penyuluhan yang dilaksanakan di SMK Profita bertujuan untuk mengembangkan kesadaran tentang pentingnya literasi kepada siswa. Melalui kegiatan MPLS dan penyuluhan literasi ini, siswa menjadi paham dan mengerti posisi gerakan literasi sebagai bagian dari wahana untuk pengembangan kompetensi siswa. Penyuluhan ini menggunakan media daring sebagai sarana penyuluhan. Media daring yang digunakan adalah zoom, google classroom, google form, dan whatsapp. Media-media ini dipilih dikarenakan mudah digunakan oleh siswa dan terbilang lebih dikenal oleh siswa.

\section{METODE}

Penyuluhan ini dilaksanakan dengan menggunakan metode deskriptif. Metode ini memaparkan cara-cara yang digunakan untuk menyelesaikan masalah. Penjelasan ini dikuatkan oleh pendapat Moleong (2002: 20) yang menjelaskan bahwa metode deskriptif adalah langkahlangkah penulis untuk mengumpulkan masalah aktual, menyusun, dan mengklasifikasikan data dengan langkah-langkah yang ditempuh. Sementara itu, secara teoretis Arikunto Suharsimi (2006: 7) menegaskan bahwa metode adalah cara-cara utama yang digunakan dalam mencapai satu tujuan.

Pada penyuluhan ini, langkah-langkah yang dilakukan adalah sebagai berikut. (1) pengumpulan data dengan observasi dan pengamatan langsung, hal ini dilakukan dengan wawancara kepda guru mata pelajaran dan penanggung jawab program Gerakan Literasi Sekolah; (2) persiapan penyuluhan yang terdiri atas persiapan materi dan media daring yang digunakan (media daring yang digunakan adalah media zoom dan google classroom) serta teknik penyuluhan; (3) pelaksanaan penyuluhan dengan proses pemberian materi melalui media daring; dan (4) hasil penyuluhan.

\section{HASIL DAN PEMBAHASAN}

Penyuluhan yang dilaksanakan di SMK Profita ini adalah penyuluhan dengan memanfatkan media daring sebagai sarana penyuluhan. Hal ini dikarenakan pandemi Covid 19 yang terus melanda negeri ini. Walaupun demikian, proses penyuluhan tetap berlangsung dengan baik. Kegiatan awal sekolah pada 13 Juli 2020 diawali dengan kegiatan MPLS secara daring. Momen inilah yang dimanfaatkan penyuluh untuk menyisipkan kegiatan penguatan gerakan literasi untuk siswa sebagai wahana memperkuat kompetensinya. 
Salah satu penerapan penyuluhan yang dilakukan adalah dengan media daring dengan memanfaatkan media daring seperti google classroom. Media daring ini memiliki keuntungan dan kemudahan dalam hal mengembangkan bahan dan mendukung pembelajaran kolaboratif melalui diskusi yang dapat dilakukan secara daring (Arriany et al., 2020: 119-120).

Hasil dan pembahasan dalam penyuluhan di SMK Profita ini akan dijelaskan berdasarkan tahapan-tahapan berikut.

\section{A. Tahap Persiapan}

Pada tahap ini, kegiatan dimulai dengan menyesuaikan kegitaan dengan jadwal MPLS di sekolah. Hal ini penting dilakukan mengingat kegiatan penyuluhan ini adalah bagian integral dari kegiatan MPLS tahun 2020. Pada tahap persiapan, penyuluh merencanakan kegiatan dengan melaksanakan tahapan observasi kegiatan dan media yang digunakan. Hal-hal yang dilakukan oleh penyuluh adalah sebagai berikut.

1. merencanakan kegiatan dengan menyesuaikan dengan jadwal kegiatan sekolah

2. merencanakan bentuk kegiatan penyuluhan

3. merencanakan media yang digunakan dalam penyuluhan

4. merencanakan sasaran siswa dalam penyuluhan

5. menyesuaikan kegiatan penyuluhan dengan program kerja GLS di SMK Profita

Tahapan-tahapan tersebut menunjukkan tahap perencanaan yang harus dipersiapkan sedemikian rupa dengan mengedepankan protokol kesehatan dalam rangka menekan penularan Covid 19. Oleh karena penyuluhan dilaksanakan secara daring. Artinya, siswa menyimak di rumah masing-masing, sedangkan penyuluh berada di sekolah. Dengan demikian, perencanaan dalam kegiatan ini dilakukan semaksimal dan seefektif mungkin menyesuaikan dengan situasi dan kondisi pandemik Covid 19.

\section{B. Tahap Kegiatan}

Setelah tahap persiapan dinilai telah sesuai dengan program penyuluhan, tahap selanjutnya adalah tahap kegiatan. Hal yang utama dari tahap kegiatan ini adalah penyampaian materi tentang pentingnya literasi dalam membantu siswa membangun kompetensi dan keahliannya. Siswa SMK Profita dibagi menjadi 3 program keahlian, yaitu: Akuntansi dan keuangan lembaga; Otomatisasi tata kelola perkantoran; dan Bisnis daring pemasaran. Ketiga program keahlian tersebut menjadi bagian penting dalam memajukan siswa pada program keahliannya masing-masing.

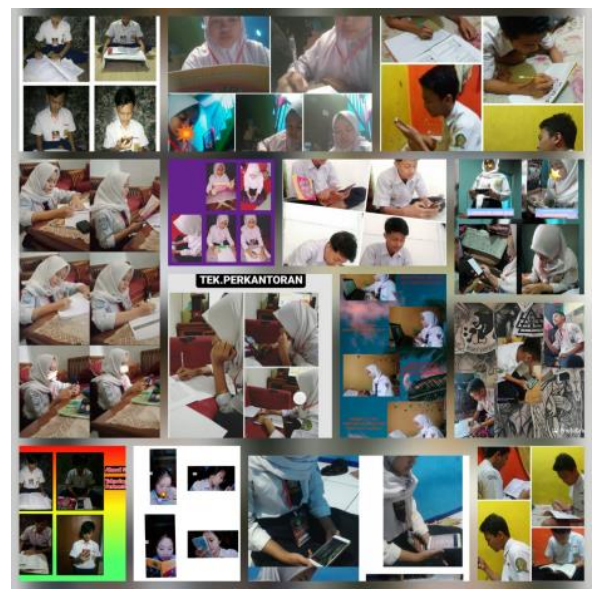

Gambar 1. Kegiatan penyuluhan literasi secara daring

Dalam kegiatan ini, ada beberapa hal yang dilakukan oleh penyuluh. Pertama, penyuluh memberikan materi literasi dengan bantuan media: powerpoint, buku panduan MPLS, dan modul singkat penyuluhan. Kegiatan bagian ini penyuluh dibantu oleh panitia MPLS. Pada bagian ini halhal yang dijelaskan oleh penyuluh adalah sebagai berikut.

1. Literasi harus sesuai dengan tahapan perkembangan 
2. Program literasi akan dilaksanakan secara berimbang sesuai kompetensi keahlian masing-masing

3. Program literasi terintegrasi dengan kurikulum dan pembiasaan literasi di sekolah sehingga menjadi tanggung jawab semua warga sekolah

4. Kegiatan literasi dilakukan kapan pun dan bermakna

5. Kegiatan literasi harus dikembangkan dalam skala luas dan berkesinambungan

Hal-hal tersebut sejalan dengan pendapat Mulyo Teguh (Rohman, 2017: 170-171) tentang prinsip-prinsip GLS baik sehingga dapat berimplikasi terhadap budaya literasi yang lebih baik dan efektif.

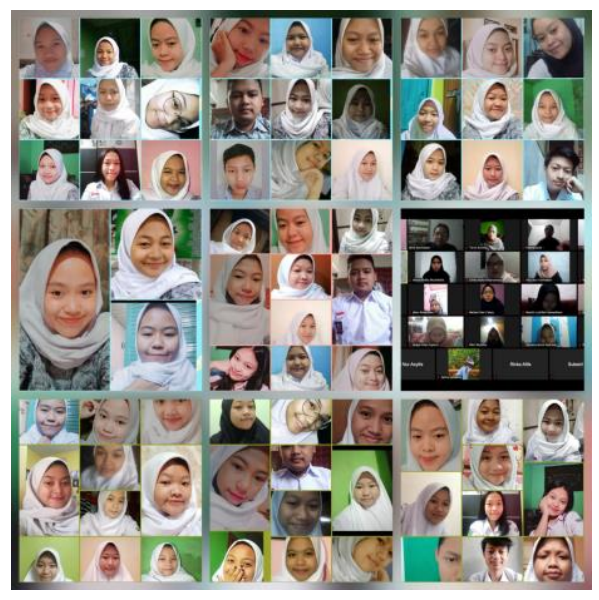

Gambar 2. Kegiatan penyuluhan literasi secara daring media Google Classroom dan Zoom

Kedua, penyuluh memberikan informasi terkait dengan bahan-bahan buku yang layak dalam rangka memperkuat literasi di sekolah. Berdasarkan hasil kegiatan penyuluhan, ada beberapa kriteria dan karakteristik buku-buku bacaan yang memiliki daya untuk perkembangan intelektual siswa, yakni sebagai berikut:

1. Buku-buku bacaan narasi atau eksplanasi yang mengandung urutan logis dari yang sederhana ke yang lebih kompleks.

2. Buku-buku bacaan yang menampilkan cerita yang sederhana baik yang menyangkut masalah yang dikisahkan, cara pengisahan, maupun jumlah tokoh yang dilibatkan.

3. Buku-buku bacaan yang menampilkan berbagai objek gambar secara bervariasi, bahkan mungkin yang dalam bentuk diagram dan model sederhana.

4. Buku-buku bacaan narasi yang menampilkan narator yang mengisah-kan cerita, atau cerita yang dapat membawa anak untuk memproyeksikan dirinya ke waktu atau tempat lain. Dalam masa ini anak sudah dapat terlibat memikirkan dan memecahkan persoalan yang dihadapi tokoh protagonis atau memprediksikan (Piaget, 2001: 86).

Berdasarkan penjelasan tersebut dapat disimpulkan bahwa kegiatan penyuluhan dengan menekankan gerakan literasi menjadi bagian yang sangat penting dalam upaya membantu siswa mengembangkan kompetensinya, terutama siswa SMK. Hal ini sudah ditegaskan pada pemaparan sebelumnya bahwa siswa SMK memiliki kemampuan dalam ranah produktif (pada mata pelajaran kejuruan). Dengan demikian, kesadaran pentingnya literasi menjadi penting untuk membangun dan memupuk hal ini.

\section{Evaluasi Kegiatan}

Tahap ketiga pada kegiatan penyuluhan ini adalah tahap evaluasi kegiatan. Berdasarkan kegiatan ini, muncul beberapa dampak yang harus dibenahi terkait program Gerakan Literasi di SMK Profita kota Bandung. Hal-hal yang harus dibenahi adalah hal-hal sebagai berikut.

1. Sistem pembelajaran yang berjalan belum menjadi wahana dalam memicu siswa memiliki minat baca yang tinggi 
2. Pembelajaran msih berpusat pda guru

3. Terlalu banyak hiburan lain sehingga siswa tidak tertarik dengan buku

4. Siswa lebih senang mendengarkan daripada membaca

5. Sumber bacaan yang minim dan tidak menarik

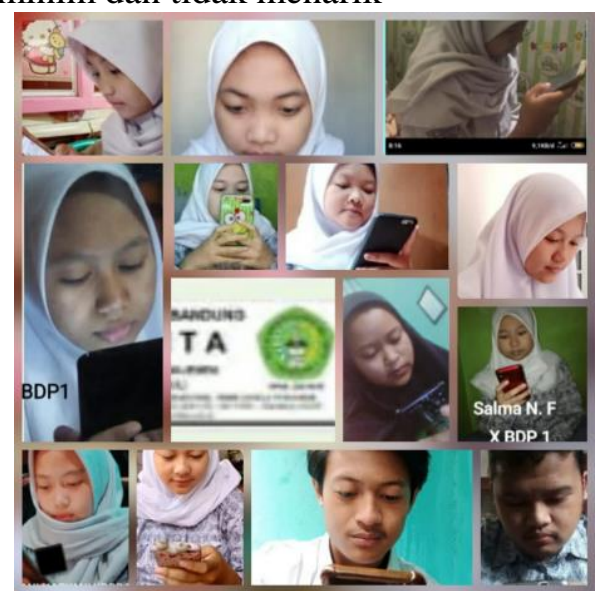

Gambar 3. Kegiatan penyuluhan literasi secara daring media Google Classroom dan Zoom

Dengan demikian, kegiatan penyuluhan yang diadakan di SMK Profita kota Bandung ini menjadi kunci dalam memupuk kesadaran siswa akan pentingnya literasi. Gerakan Literasi Sekolah diharapkan menjadi bahan untuk proses pembelajaran yang lebih luas (Taufani, 2008: 52).

Manfaat dari penyuluhan ini diharapkan dapat meningkatkan peran sekolah dalam rangka membina dan memupuk kegiatan literasi supaya menjadi lebih efektif dan berjalan berkesinambungan. Di samping itu, siswa dan guru wajib memberi dukungan penuh terhadap upaya-upaya meningkatkan literasi di sekolah. Harapnnya literasi menjadi tempat memompa pengetahuan yang menyenangkan/kegembiraan, learning is most effective when it is fun, kegembiraan disini berarti bangkitnya minat, adanya keterlibatan penuh, serta terciptanya makna, pemahaman (penguasaan atas materi yang dipelajari), dan nilai yang membahagiakan pada diri siswa (Isnaini \& Herliani, 2020: 82).

\section{SIMPULAN}

Kegiatan penyuluhan ini adalah program pengabdian pada masyarakat dalam dunia pendidikan. Kegiatan yang diadakan adalah kegiatan penguatan tentang pentingnya literasi terhadap kemampuan dan peningkatan kompetensi siswa SMK di masa pandemik Covid 19. Kegiatan ini terdiri atas 3 tahap, yaitu: tahap perencanaan, tahap kegiatan, dan tahap evaluasi.

Tahap perencanaan meliputi: merencanakan kegiatan dengan menyesuaikan dengan jadwal kegiatan sekolah; merencanakan bentuk kegiatan penyuluhan; merencanakan media yang digunakan dalam penyuluhan; merencanakan sasaran siswa dalam penyuluhan; dan menyesuaikan kegiatan penyuluhan dengan program kerja GLS di SMK Profita. Adapun tahap pelaksanaan adalah kegiatan yang dilakukan dengan pemberian materi melalui media daring (google classroom, whatsapp, dan zoom meeting); pengenalan program GLS; dan bahan-bahan yang menarik untuk membantu terrealisasinya program GLS. Tahap evaluasi menjadi penekanan terhadap kegiatan ini karena melalui kegiatan ini terkuak hambatan dan halangan dalam mengembangkan kegiatn literasi di SMK Profita.

Dengan demikian, kegiatan penyuluhan ini diharapkan dapat memupuk kemampuan siswa dengan menerapkan Gerakan Literasi Sekolah yang maksimal dan efektif. Selain itu, peran warga sekolah, seperti kepala sekolah, guru, dan siswa menjadi elemen penting dalam menciptakan gerakan literasi yang efektif dan produktif.

\section{SARAN}

Kegiatan penyuluhan ini tentu saja terdapat banyak kekuarangan di berbagai segi. Hal ini akan diperbaiki dan disempurnakan pada kegiatan penyuluhan selanjutnya. Kekurangan-kekurangan 
yang muncul di antaranya karena media daring yang digunakan serta teknik penyuluhan. Selain itu, kegiatan penyuluhan akan penguatan kegiatan literasi dari berbagai segi dan kegiatan. Dengan demikian, peran guru di sekolah dan penyuluh di perguruan tinggi akan semakin baik dalam mendorong kemajuan program Gerakan Literasi Sekolah.

\section{UCAPAN TERIMA KASIH}

Kami mengucapkan terima kasih kepada pihak-pihak yang membantu dalam kegiatan penyuluhan dan pemublikasian artikel ini. Beberapa pihak tersebut diantaranya: (1) Ketua Yayasan Pendidikan Ekonomi Bandung, Kepala SMK Profita Bandung, Guru, Staf TU, dan para siswa SMK Profita Bandung; (2) Rektor IKIP Siliwangi, Dekan Fakultas Pendidikan Bahasa, dan Ketua Prodi Pendidikan Bahasa dan Sastra Indonesia; (3) Rektor Universitas Wisnuwardhana, Malang, Dekan Fakultas Pendidikan, dan Ketua Prodi Pendidikan Bahasa Indonesia; (4) Kepala LPM Community Development Journal, Universitas Pahlawan Tuanku Tambusai, Bangkinang; dan (5) semua pihak yang membantu dan tidak dapat disebutkan satu persatu.

\section{DAFTAR PUSTAKA}

Arriany, I., Junadi, \& Laksono, A. D. (2020). Pelatihan E-Learning untuk Tutor Pendidikan Kesetaraan. Community Development Journal, Vol. 1 No. 2, 118-124.

Budiharto, Triyono, \& Suparman. (2018). Literasi Sekolah sebagai Upaya Penciptaan Masyarakat Pembelajar yang Berdampak pada Peningkatan Kualitas Pendidikan. Jurnal Seuneubok: Jurnal Ilmu-Ilmu Sejarah, Sosial, Budaya, dan Kependidikan, Volume 5, No. 1, 153-166.

Gardner, H. (1983). Frame of Mind: The Theory of Multiple Intelegences. New York: New York Basic Book.

Isnaini, H., \& Herliani, Y. (2020). Penyuluhuan Pembelajaran Menulis Puisi Berbasis Karakter di SMK Profita Kota Bandung Tahun Ajaran 2019-2020. Community Development Journal, Vol 1 No. 1 2, 78-83. $\quad$ Retrieved from https://journal.universitaspahlawan.ac.id/index.php/cdj/article/view/707/pdf

Moleong, L. J. (2002). Metodologi Penelitian Kualitatif. Bandung: Remaja Rosdakarya.

Mujiwati, Y., Paramitha, M., \& Maulana, M. Z. A. S. (2020). Menumbuhkan Rasa Kepedulian Siswa Terhadap Kebersihan Lingkungan di Sekolah MA Al Masyhur Bugul Kidul Kota Pasuruan. Community Development Journal, Vol. 1, No. 2, 157-164.

Nopilda, L., \& Kristiawan, M. (2018). Gerakan Literasi Sekolah Berbasis Pembelajaran Multiliterasi sebuah Paradigma Pendidikan Abad ke-21. JMKSP (Jurnal Manajemen, Kepemimpinan, dan Supervisi Pendidikan), Volume 3, No. 2, 217-231.

Piaget, J. (2001). Teori Perkembangan Kognitif (P. Suparno, Trans.). Yogyakarta: Kanisius.

Rohman, S. (2017). Membangun Budaya Membaca pada Anak Melalui Program Gerakan Literasi Sekolah. Jurnal Terampil: Jurnal Pendidikan dan Pembelajaran Dasar, Volume 4 Nomor $1,151-174$.

Suharsimi, A. (2006). Prosedur Penelitian. Bandung: Alfabeta.

Taufani, G. K. (2008). Menginstal Minat Baca Peserta Didik. Bandung: PT Globalindo Universal Multikreasi.

Wandasari, Y. (2017). Implementasi Gerakan Literasi Sekolah (GLS) sebagai Pembentuk Pendidikan Berkarakter. JMKSP (Jurnal Manajemen, Kepemimpinan, dan Supervisi Pendidikan), Volume 1, No.1, 325-342. 